\title{
STUDY OF VARIOUS DESIGN METHODS FOR COLD - FORMED LIGHT GAUGE STEEL SECTIONS FOR COMPRESIVE STRENGTH
}

\author{
S.A.Kakade ${ }^{1}$, B.A.Bhandarkar ${ }^{2}$, S.K. Sonar ${ }^{3}$, A.D.Samare ${ }^{4}$ \\ ${ }^{1}$ Asst.Professor, Civil Engg Dept, G.H.R.I.E.M Jalgaon, MH, India \\ ${ }^{2}$ Asst.Professor, Civil Engg Dept, G.H.R.I.E.M Jalgaon, MH, India \\ ${ }^{3}$ Lecturer, Civil Engg Dept, G.H.R.I.E.M Jalgaon, MH, India \\ ${ }^{4}$ Asst.Professor, Civil Engg Dept, J.I.E.M.S Akkalkuva, MH, India
}

\begin{abstract}
As the steel is tested for all types of tests viz, compressive, tensile test, shear test, torsion test, etc. This paper provides an experimental investigation for the compressive strength of Cold-Formed light gauge steel plain (stiffened) tubular sections. The test specimens were brake pressed from high strength structural steel sheets. In addition, the test strengths were compared with the design strengths calculated using the Indian Standard and North American Specification for Cold-Formed steel structures. Compression members are linear members in which axial forces act to cause elongation (stretch). Such members can sustain loads up to the ultimate load, at which stage they may fail by rupture at a critical section. However, if the gross area of the member yields over a major portion of its length before the rupture load is reached, the member may become non - functional due to excessive elongation. I.S. 801- 1975 is in Working Stress Method (W.S.M.) and in (M.K.S.) system. So it is required to study Allowable Stress Design (A.S.D.), Load and Resistance-Factor-Design (L.R.F.D.) and Limit State Method (L.S.M.).It is revealed that the design strengths predicted by the Specification and Standard are generally very conservative. It is observed that some specimen show lower strength than the value predicted by the American Iron and Steel Institute.
\end{abstract}

Keywords: Cold - Formed steel, Compressive strength, stiffened.

\section{INTRODUCTION}

Cold - Formed steel members are widely employed in steel construction because they are lighter and more economical than traditional hot-rolled sections. In recent years, Allowable Stress Design (A.S.D.) and Load and Resistance - Factor - Design (L.R.F.D.) methods has been successfully applied to the design of hot-rolled steel sections and cold Formed steel members in the United States and other countries. L.R.F.D. method is used for the design of Cold Formed steel structural members and connections. The design of Cold - Formed steel section is done by using I.S. 801-1975. This results in uneconomic design because in W.S.M. full section is not utilized. So to utilize the full cross - section of the section and to maintain economy, it is required to revise Indian Standard Code and also in S.I. system.

\section{BRIEF HISTORY}

Cold - Formed steel applications can be traced back as early as the 1850 s in both the United States and Great Britain in the later 1920s and early 1930s Cold - Formed steel entered. The building construction arena with products manufactured. By a handful of fabricators. Although these products were successful in performance, they faced difficulties with acceptance for two reasons:

i. There was no standard design methodology available, and ii. Cold - Formed steel was not included in the building codes at that time. Many of the Cold - Formed steel applications were unable to be used due to the lack of design methodology and product recognition. To face this challenge, America Iron and Steel Institute (A.I.S.I.) convened a technical committee in 1938, known as the Committee on Building Code, with the mission of developing a specification or the design of Cold - Formed steel structures. Research work was conducted at Cornell University, led by Professor George Winter. Eight years later, in 1946, the first Specification for the Design of Light Gauge Steel Structural Members was published, and in 1949, the first Design Manual was available for use by design engineers. After the publication of the second edition in 1956, the Specification was formally opening the door towards acceptance of Cold - Formed steel products. To increase the market share of Cold - Formed steel, A.I.S.I. has been continually providing research funding to broaden the design coverage, improve the design technology, and cultivates Cold - Formed steel community. After ten years of mutual efforts, the first edition of the North American Specification for the Design of Cold - Formed Steel Structural Members was published in 2001.This document was immediately adopted by the International Building Code and was recognized by the American National Standards Institute (A.N.S.I.) as the National Standard in the United States.

\section{ADVANTAGES OF COLD - FORMED STEEL}

1. Lightweight

2. High strength and stiffness

3. Fast and easy erection and installation

4. Dimensionally sTable material 
5. No formwork needed

6. Durable material

7. Economy in transportation

8. East for handling

9. Non-combustible material

10. Recyclable nature

\section{EXPERIMENTAL INVESTIGATION}

The purpose of the test is to know the elastic properties, Compressive strength and ductility of the steel. From this test we can obtain; stress strain relationship, modulus of elasticity, yield strength, ultimate tensile strength and percentage elongation of steel materials under compressive load

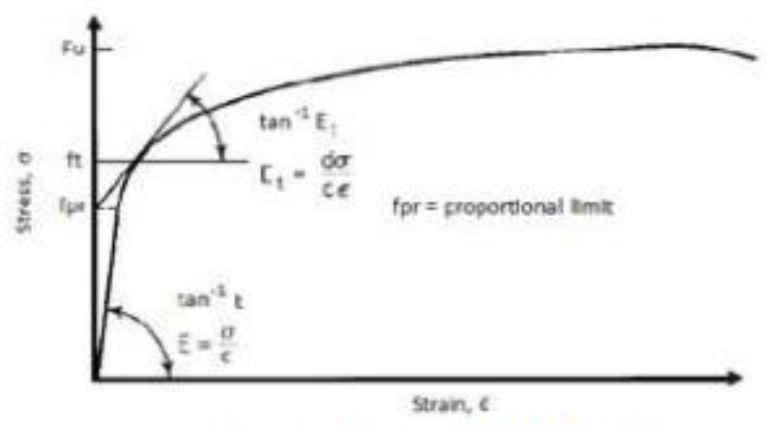

Figure 1. Typical Stress - Strain Curve

For Allowable Stress Design (A.S.D.) and Load and Resistance - Factor - Design (L.R.F.D.) methods, it can be seen that the nominal Compressive strength of axially loaded Cold - Formed steel members is determined either by yielding of the gross sectional area or by rupture of the net area of the cross section. In addition to the strength consideration, yielding in the gross section also provides a limit on the deformation that a tension member can achieve. For Limit State Method (L.S.M.), the design strength of a member under axial tension is the lowest of the design strength due to yielding of gross section, rupture strength of critical section, and block shear respectively. Cold forming has the effect of increasing the yield strength of steel, the increase being the consequence of cold working well into the strain-hardening range. This increase is in the zones where the material is deformed by bending or working. The yield stress can be assumed to have been increased by $15 \%$ or more for design purposes. The yield stress value of cold formed steel is usually between $33 \mathrm{ksi}(228 \mathrm{MPa})$ and $80 \mathrm{ksi}$ (552 MPa). The compressive test was conducted by taking the specimen Dimensions as given below:

The experiment was investigated by using the rectangular and circular hollow section of sizes as given below.

\subsection{Specimen Labeling}

RHS $160 \mathrm{~mm} \times 30 \mathrm{~mm} \times 1.5 \mathrm{~mm}$

RHS $250 \mathrm{~mm} \times 25 \mathrm{~mm} \times 1.9 \mathrm{~mm}$

RHS $340 \mathrm{~mm} \times 20 \mathrm{~mm} \times 1.0 \mathrm{~mm}$

CHS 1: $50.8 \mathrm{~mm} \times 1.9 \mathrm{~mm}$

CHS 2: $19.5 \mathrm{~mm} \times 1.6 \mathrm{~mm}$
CHS 3: $31.75 \mathrm{~mm} \times 1.15 \mathrm{~mm}$

Table 1 maximum compressive strength of RHS 1

\begin{tabular}{|c|c|c|}
\hline $\begin{array}{l}\text { SR. } \\
\text { NO }\end{array}$ & $\begin{array}{l}\text { DESIGN } \\
\text { METHODS }\end{array}$ & $\begin{array}{l}\text { LOAD CARRYING } \\
\text { CAPACITY }(\mathrm{kN})\end{array}$ \\
\hline 1 & A.S.D. & 36.831 \\
\hline 2 & L.R.F.D. & 69.786 \\
\hline 3 & L.S.M. & 39.753 \\
\hline 4 & W.S.M. & 27.726 \\
\hline 5 & Test Result & 57.83 \\
\hline
\end{tabular}

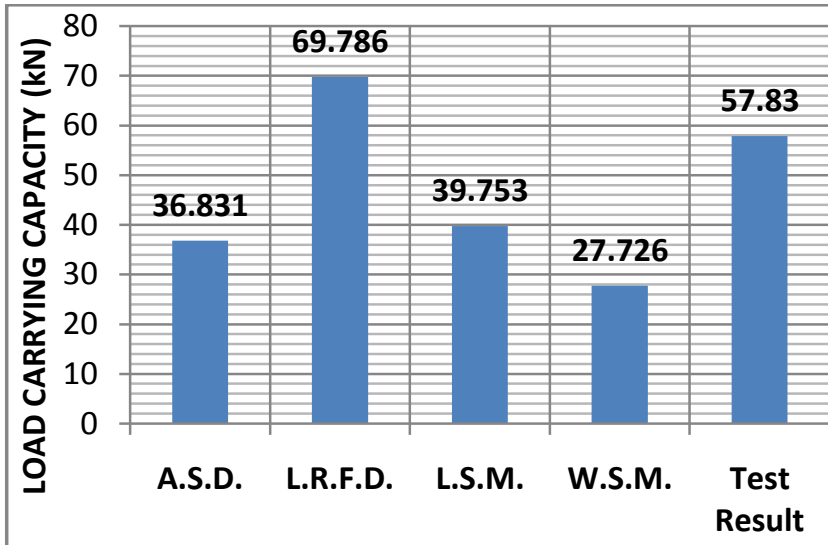

DESIGN METHODS

Graph 1 Showing Load Carrying Capacity of RHS 1:

Table 2 maximum compressive strength of RHS 2

\begin{tabular}{|l|l|l|}
\hline $\begin{array}{l}\text { SR. } \\
\text { NO }\end{array}$ & $\begin{array}{l}\text { DESIGN } \\
\text { METOD }\end{array}$ & $\begin{array}{l}\text { LOAD CARRYING } \\
\text { CAPACITY }(\mathrm{kN})\end{array}$ \\
\hline 1 & A.S.D. & 40.35 \\
\hline 2 & L.R.F.D. & 76.454 \\
\hline 3 & L.S.M. & 36.726 \\
\hline 4 & W.S.M. & 28.464 \\
\hline 5 & Test result & 69.66 \\
\hline
\end{tabular}

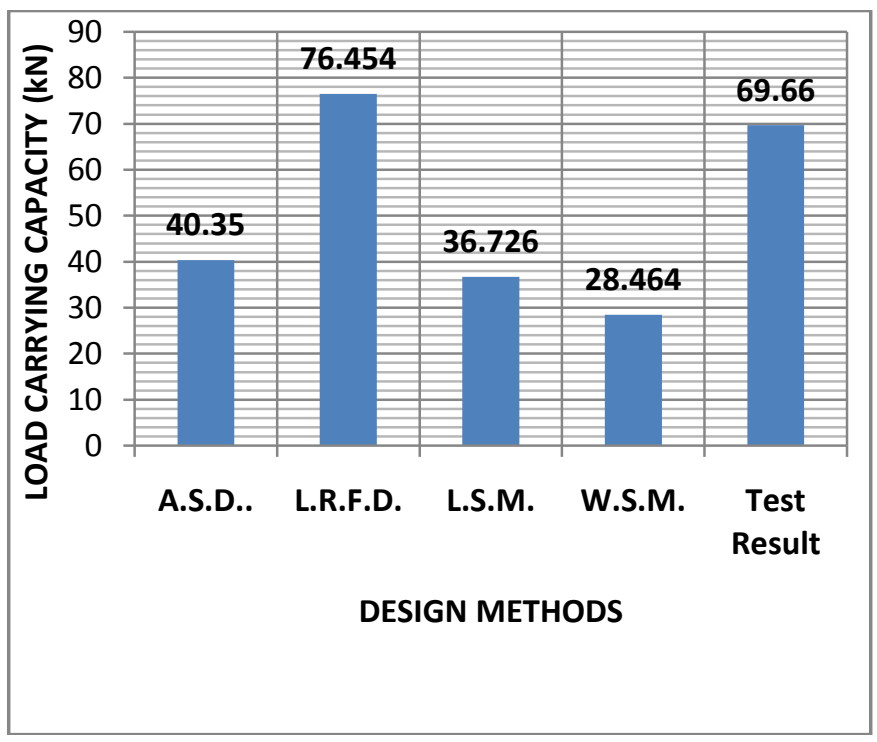

Graph 2 Showing Load Carrying Capacity of RHS 2 
Table 3 maximum compressive strength of RHS 3

\begin{tabular}{|l|l|l|}
\hline $\begin{array}{l}\text { Sr. } \\
\text { No. }\end{array}$ & Design Method & $\begin{array}{l}\text { Load Carrying } \\
\text { Capacity }(\mathrm{kN})\end{array}$ \\
\hline 1 & A.S.D. & $24 . .594$ \\
\hline 2 & L.R.F.D. & 46.626 \\
\hline 3 & L.S.M. & 15.361 \\
\hline 4 & W.S.M. & 12.055 \\
\hline 5 & Test result & 26.33 \\
\hline
\end{tabular}

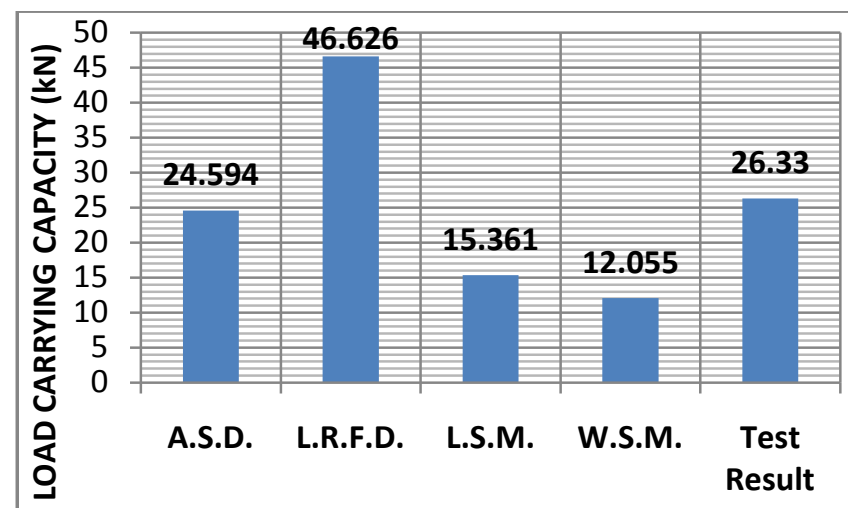

DESIGN METHODS

Graph 3 Showing Load Carrying Capacity of RHS 3

Table 4 Load Carrying Capacity of CHS 1

\begin{tabular}{|l|l|l|}
\hline Sr. No. & Various Methods & $\begin{array}{l}\text { Load Carrying Capacity } \\
(\mathrm{kN})\end{array}$ \\
\hline 1 & A.S.D. & 41.287 \\
\hline 2 & L.R.F.D. & 78.228 \\
\hline 3 & L.S.M. & 51.993 \\
\hline 4 & W.S.M. & 31.000 \\
\hline 5 & Test Result & 70.500 \\
\hline
\end{tabular}

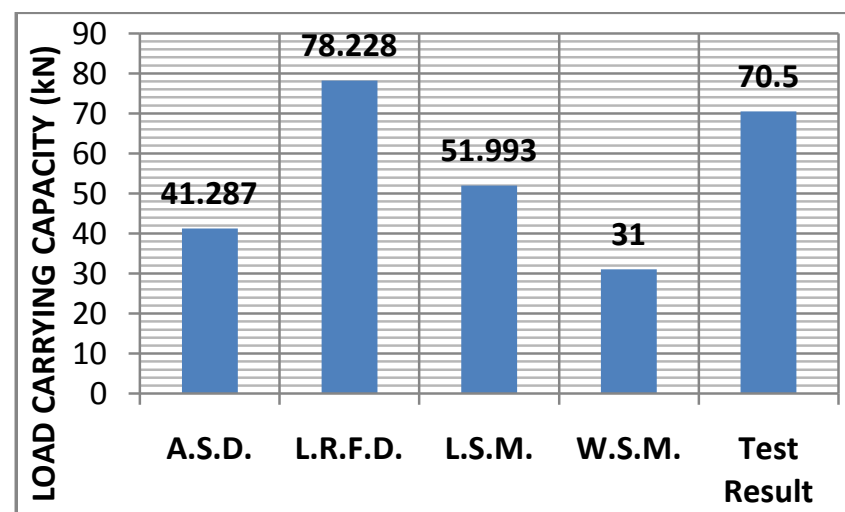

DESIGN METHODS

Graph 4 Showing Load Carrying Capacity of CHS 1

Table 5 Load Carrying Capacity of CHS 2

\begin{tabular}{|l|l|l|}
\hline Sr. No. & Various Methods & $\begin{array}{l}\text { Load Carrying } \\
\text { Capacity }(\mathrm{kN})\end{array}$ \\
\hline 1 & A.S.D. & 13.421 \\
\hline 2 & L.R.F.D. & 25.123 \\
\hline 3 & L.S.M. & 10.165 \\
\hline
\end{tabular}

\begin{tabular}{|l|l|l|}
\hline 4 & W.S.M. & 8.851 \\
\hline 5 & Test Result & 11.660 \\
\hline
\end{tabular}

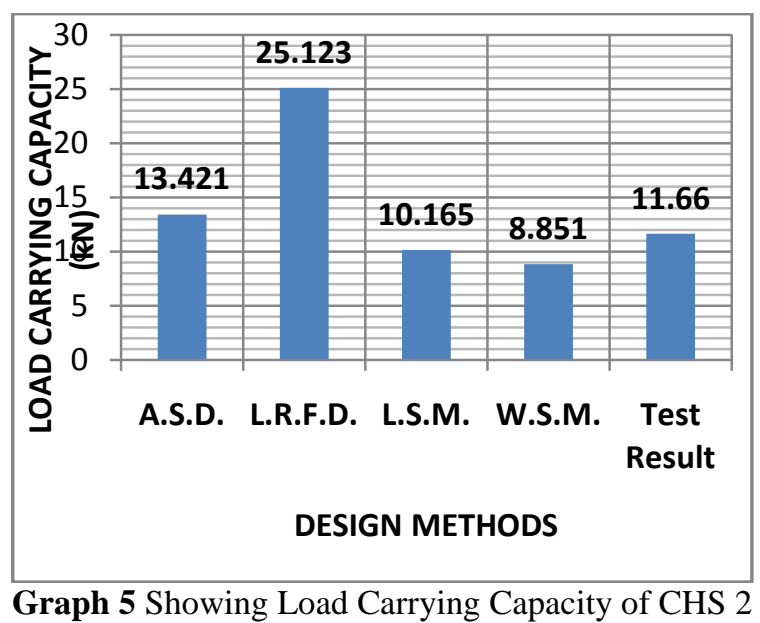

Table 6 Load Carrying Capacity of CHS 3

\begin{tabular}{|l|l|l|}
\hline Sr. No. & Various Methods & $\begin{array}{l}\text { Load Carrying Capacity } \\
(\mathrm{kN})\end{array}$ \\
\hline 1 & A.S.D. & 21.440 \\
\hline 2 & L.R.F.D. & 40.624 \\
\hline 3 & L.S.M. & 17.617 \\
\hline 4 & W.S.M. & 11.470 \\
\hline 5 & Test Result & 23.200 \\
\hline
\end{tabular}

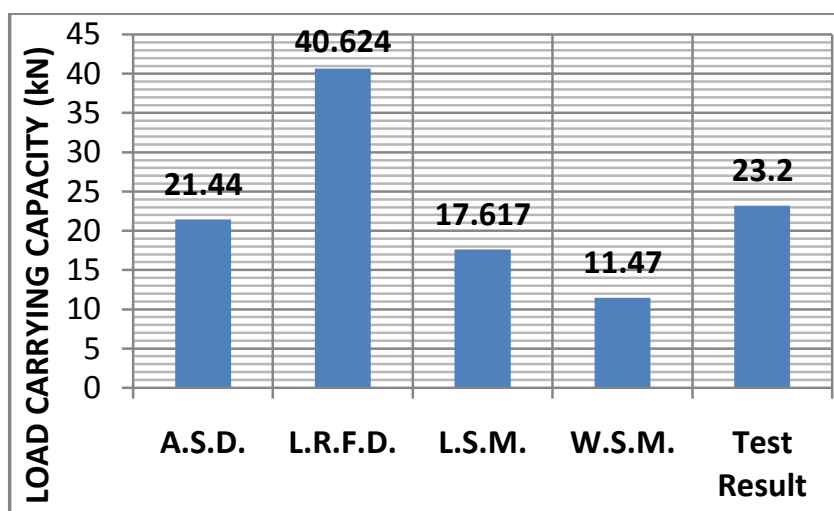

DESIGN METHODS

Graph 6 Showing Load Carrying Capacity of CHS 3

\section{CONCLUSIONS}

- The full cross section is not utilized by I.S. 801:1975, because of working stress method.

- The full cross section is utilized by I.S. 800:2007, because of limit state method.

- The I.S. 801:1975 which is in the working stress method and in M.K.S. system has to revise to limit state method and in S.I. method.

- Load and Resistance Factored Design Method gives greater values as compared to test results, hence it is over estimated. 


\section{REFERENCES}

[1]. B. C. Punmia, A. K. Jain, and A. K. Jain, "Comprehensive Design of Steel Structures", 2nd ed., 2008, Laxmi, New Delhi.

[2]. I.S 800: 2007, "Indian Standard General Construction in Steel - Code of Practice", Bureau of Indian Standards, New Delhi. India.

[3]. I.S. 801: 1975, "Indian Standard Code of Practice for Use of Cold-Formed Light Gauge Steel Structural Members in General Building Construction", Bureau of Indian Standards, New Delhi. India.

[4]. I.S. 811: 1987, "Indian Standard Specification for ColdFormed Light Gauge Structural Steel Sections", Bureau of Indian Standards, New Delhi. India.

[5]. M. R. Shiyekar, "Limit State Design in structural steel" 2010, PHI Learning Private Limited, New Delhi.

[6]. North American Cold-formed Steel Specification (NAS). "North American Specification for the design of cold-formed steel structural members", 2001, American Iron and Steel Institute, Washington, D.C.

[7]. W. W. Yu, "Cold-formed steel design", 3rd ed., 2000, Wiley, New York.

[8]. W. W. Yu, "Cold-formed steel design", 4th ed., 2010, Wiley, New York.

\section{BIOGRAPHIES}

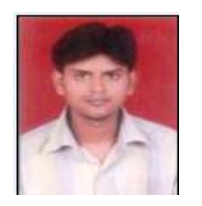

S.A.Kakade worked as Asst.Prof. at G.H.RI.E.M., Jalgaon

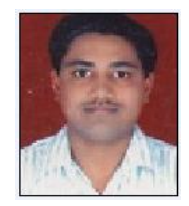

B.A.Bhandarkar worked as Asst.Prof. at G.H.RI.E.M., Jalgaon

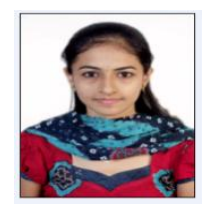

S.K. Sonar worked as Asst.Prof. at G.H.RI.E.M., Jalgaon

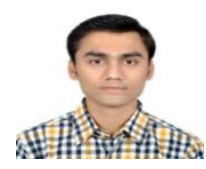
A.D.Samare worked as Asst.Prof. at J.I.E.M.S 